\title{
Perbandingan Penanganan Clubfoot Metode Kite-Lovell dengan Ponseti
}

\author{
Andri Primadhi, Yoyos D. Ismiarto \\ Bagian Orthopaedi dan Traumatologi \\ Fakultas Kedokteran Universitas Padjadjaran \\ Rumah Sakit Hasan Sadikin, Bandung
}

\begin{abstract}
Abstrak
Clubfoot banyak terjadi pada bayi baru lahir dan akan menghambat anak untuk berjalan. Bila kelainan ini tidak ditangani dengan benar, akan menetap sampai dewasa dan mempengaruhi kualitas hidupnya. Umumnya penatalaksanaan inisial clubfoot menggunakan cara konservatif, walaupun pemilihan metode manipulasi masih menjadi kontroversi. Penanganan clubfoot di RS Hasan Sadikin Bandung (RSHS) menggunakan metode KiteLovell dan Ponseti, yang berbeda dalam teknik manipulasinya. Sejumlah penelitian menyebutkan bahwa penatalaksanaan clubfoot dengan metode Ponseti lebih baik dibandingkan Kite-Lovell. Penelitian ini membandingkan hasil penanganan clubfoot menggunakan kedua metode tahun 2001-2005. Penelitian ini menggunakan desain cross sectional dengan data yang diambil dari rekam medis pasien clubfoot di RSHS, terdiri dari karakteristik pasien, metode, serta kemajuan pasien tersebut, diukur menggunakan skoring Dimeglio. Jumlah pasien ada 64 anak, atau 103 kaki karena tidak semua anak memiliki kelainan bilateral. Hasil penelitian menunjukkan bahwa jumlah pasien laki-laki lebih dominan yaitu 36 anak (56\%). Bila digolongkan menurut usia saat pertama kali berobat, persentase terbanyak ialah pada kelompok usia paling dini, yaitu 0-3 bulan (34 anak). Sebanyak 71 kaki (69\%) ditangani dengan metode Kite-Lovell sedangkan sisanya dengan metode Ponseti. Dengan skoring Dimeglio, tidak ditemukan perbedaan yang bermakna pada hasil penanganan antara kedua metode, tetapi angka keberhasilan akan lebih tinggi bila penanganan dilakukan pada usia lebih dini.
\end{abstract}

[MKB. 2009;41(4):207-11].

Kata kunci: Clubfoot, metode Kite-Lovell, metode Ponseti

\section{Comparison Between Kite-Lovell Method and Ponseti in Clubfoot Treatment}

\begin{abstract}
Clubfoot is anomalies frequently seen in the newborns. This limits the child's walking ability. Without adequate treatment, it will interfere the patient's living. Treatment consists of conservative and operative. Conservative treatment is initial choice, with controversies about its methods. Conservative treatment consists of Kite-Lovell and Ponseti methods. There is difference between them in the matter of manipulation. Numbers of study said that the Ponseti methods gave better result than Kite-Lovell. This study was to compare about the two methods performed in Hasan Sadikin General Hospital in the year of 2001-2005. The design was cross sectional. Data collected from the medical records from 2001 to 2005, including characteristic, methods used, and clinical improvement that measured by Dimeglio scoring system. This research included 64 children, or 103 foot, due to not all the children had bilateral clubfoot. The results showed that male patients were dominant (56\%). According to age at initial treatment, the most common was 0-3 years, i.e. 34 children. Seventy-one feet (69\%) were treated with Kite-Lovell methods, and the rests by Ponseti methods. Using Dimeglio scoring, we measured the initial and final scores, and there was no significant difference between them, but the results are better if done at younger age. [MKB. 2009;41(4):207-11].
\end{abstract}

Key words: Clubfoot, Kite-Lovell method, Ponseti method

Korespondensi: Andri Primadhi, dr., Bagian Orthopaedi dan Traumatologi, Fakultas Kedokteran Universitas Padjadjaran, Rumah Sakit Hasan Sadikin, Jln. Pasteur 38 Bandung, Telp. (022) 2035477, e-mail : andriprim@yahoo.com 


\section{Pendahuluan}

Congenital talipes equinovarus (CTEV) atau clubfoot merupakan terminologi yang digunakan untuk mendeskripsikan kelainan yang bersifat kompleks, kongenital, serta kontraktural pada tulang dan sendi di daerah kaki dan pergelangan kaki. ${ }^{1}$ Clubfoot merupakan kelainan bawaan yang sering ditemukan pada bayi baru lahir dengan insidensi 0,93 sampai 1,5 per 1.000 kelahiran pada ras kaukasia, sedangkan di daerah Asia angka insidensinya sebesar 0,6 per 1.000 kelahiran. Anak laki-laki terkena dua kali lebih banyak dibandingkan dengan perempuan dan pada $50 \%$ kasus ditemukan keterlibatan kedua kaki. ${ }^{1-5}$

Penanganan terhadap clubfoot telah tercatat sejak zaman sebelum Masehi oleh Hippocrates (460-377 SM) menyatakan bahwa melakukan manipulasi pada kaki seharusnya dengan lembut seperti membentuk patung lilin, bukan semata dengan kekuatan. ${ }^{4}$ Pengobatan terhadap clubfoot sendiri terdiri dari cara konservatif dan operatif. Pada awalnya penanganan operatif berupa soft tissue release disukai oleh berbagai kalangan, dengan hasil akhir yang memuaskan. Namun, follow up jangka panjang yaitu 10-15 tahun menunjukkan efek samping yang mengecewakan, mencakup nyeri dan gangguan fungsional. Komplikasi jangka menengah meliputi nekrosis jaringan, infeksi, nekrosis avaskular tulang talus, koreksi yang terlalu banyak, dan rekurensi. Komplikasi jangka panjang meliputi kelemahan otot, pemendekan kaki, kekakuan, dan perubahan sendi.

Secara umum disetujui bahwa pengobatan inisial terhadap clubfoot sebaiknya dengan cara konservatif/nonoperatif, walaupun teknik manipulasi yang dipilih masih tetap kontroversial., ${ }^{1,5}$ Ada banyak cara untuk penanganan clubfoot, sebagaimana banyaknya jumlah pakar yang pernah menulis tentang clubfoot. ${ }^{5}$

Di RS Hasan Sadikin Bandung (RSHS), dilakukan pula penanganan secara konservatif maupun operatif. Cara konservatif yang digunakan ialah dengan metode Kite-Lovell dan metode Ponseti yang lebih baru. Di antara keduanya terdapat perbedaan dalam hal teknik manipulasi. ${ }^{6}$

Perlu diketahui apakah terdapat perbedaan hasil penanganan antara CTEV dengan metode Kite-Lovell, dan metode Ponseti, sehingga dapat menjadi pedoman dalam pemilihan teknik manipulasi yang akan digunakan dalam penanganan pasien clubfoot.

Penanganan untuk clubfoot sebaiknya sedini mungkin, dalam waktu satu atau dua hari setelah kelahiran. ${ }^{5}$ Inti penanganan mencakup langkahlangkah dasar berupa koreksi deformitas dengan lembut, mempertahankan koreksi dalam waktu yang lama, dan pemantauan terhadap penderita sampai akhir masa pertumbuhan. Bahkan setelah tercapainya koreksi penuh, kegagalan jaringan lunak yang mengalami kontraktur untuk tumbuh memanjang akan dapat menimbulkan rekurensi, biasanya pada saat tulang tumbuh dengan cepat. ${ }^{7}$

\section{Metode}

Subjek penelitian adalah pasien clubfoot yang terapi inisialnya secara konservatif dan telah menyelesaikan serial casting.

Penelitian ini menggunakan studi cross sectional dengan berlandaskan data yang didapat dari rekam medis pasien yang mendapatkan penanganan di Bagian Orthopaedi dan Traumatologi RS Hasan Sadikin Bandung selama periode 20012005 dengan cara konservatif menggunakan metode Kite-Lovell dan Ponseti.

Metode Kite-Lovell sudah dipopulerkan sejak lama, disebut teknik tradisional, dan dilakukan di RSHS sampai dengan tahun 2004. Metode ini diawali dengan manipulasi untuk mengkoreksi adduksi, kemudian melakukan supinasi secara simultan pada kaki tanpa memberikan tekanan pada talar head. ${ }^{8}$ Dengan metode ini, koreksi equinus dilakukan pada awal terapi. Bagian midfoot tidak boleh diregangkan terlalu kuat, dan jangan dipaksakan dorsifleksi pada forefoot, karena akan dapat menyebabkan terjadinya deformitas rocker bottom pada kaki berupa malposisi sumbu talus menjadi lebih vertikal. ${ }^{2}$

Menurut Kite, heel varus dapat dikoreksi langsung dengan mengeversikan kalkaneus. Ia tidak menyadari bahwa kalkaneus hanya dapat dieversikan bila berada dalam keadaan abduksi, yaitu dirotasikan ke lateral di bawah talus. Mengabduksikan kaki pada sendi midtarsal dengan ibu jari menekan ke sisi lateral kaki dekat sendi calcaneocuboid akan memblok abduksi kalkaneus dan akan mengganggu koreksi heel varus.

Metode lain diperkenalkan oleh Dr. Ignacio V. Ponseti sejak tahun 1963 melalui The Journal of Bone and Joint Surgery. Metode ini diperkenalkan oleh Dr. Ponseti berdasarkan pendangan beliau, 
Tabel 1 Klasifikasi Sistem Skoring Dimeglio

\begin{tabular}{cccccc}
\hline Rating & $\mathbf{4}$ & $\mathbf{3}$ & $\mathbf{2}$ & $\mathbf{1}$ & $\mathbf{0}$ \\
\hline Equinus & $45-90^{\circ} \mathrm{pltf}$ & $20-45^{\circ} \mathrm{pltf}$ & $20 \mathrm{pltf}-0^{\circ}$ & $0-20^{\circ}$ dorsx & $>+20^{\circ}$ dorsx \\
Varus & $45-90^{\circ} \mathrm{var}$ & $20-45^{\circ} \mathrm{var}$ & $20-0^{\circ}$ & $0-20^{\circ} \mathrm{vlg}$ & $>20^{\circ} \mathrm{vlg}$ \\
Supination & $45-90^{\circ}$ sup & $20-45^{\circ}$ sup & 20 sup $-0^{\circ}$ & $0-20^{\circ}$ pron & $20^{\circ} \mathrm{pron}$ \\
Adductus & $45-90^{\circ}$ add & $20-45^{\circ}$ add & 20 add $-0^{\circ}$ & $0>-<20^{\circ}$ abd & $>20^{\circ}$ abd \\
Posterior Crease & & & & Ya & Tidak \\
Medial Crease & & & & Ya & Tidak \\
Cavus & & & & Ya & Tidak \\
Deviant Muscle & & & & Ya & Tidak \\
\hline
\end{tabular}

bahwa para ahli orthopaedi sebelumnya berusaha untuk mengkoreksi supinasi yang berat pada clubfoot dengan cara mempronasikan midfoot dengan kuat. Hal ini malah akan menimbulkan cavus yang lebih besar dan kelainan pada midfoot berupa breach. Breach pada midfoot ini disebabkan oleh adanya penguncian tuberositas anterior dari kalkaneus yang teradduksi melawan permukaan bawah talar head. Menurutnya, clubfoot dapat dikoreksi dengan mudah apabila kita mengerti anatomi fungsional kaki. Kaki yang mengalami supinasi diabduksikan di bawah talus dengan melakukan kontra tekanan dengan ibu jari kita melawan aspek lateral dari talar head. Varus, inversi, dan adduksi dari hindfoot dikoreksi secara simultan karena sendi-sendi tarsal saling tergantung satu sama lain dan tidak dapat dikoreksi secara sekuensial.

Penelitian ini mengelompokkan penderita menurut jenis kelamin, cara penanganan, dan juga usia saat pertama kali mendapat penanganan. Penilaian tingkat keparahan clubfoot dibuat berdasarkan sistem skoring Dimeglio. Sistem skoring Dimeglio merupakan sistem yang cukup banyak digunakan dan cocok untuk digunakan dalam penelitian yang membandingkan parameter awal klasifikasi dan studi follow up.

Penelitian ini membandingkan antara pasien yang mendapatkan terapi konservatif metode Kite-Lovell dan metode Ponseti, dianalisis secara statistik dengan uji t-test menggunakan software SPSS versi 15.

\section{Hasil}

Sampel penelitian berjumlah 64 anak atau 103 kaki, dengan catatan bahwa tidak semua anak memiliki kelainan bilateral.

Perbadingan jumlah pasien clubfoot menurut jenis kelamin, laki-laki lebih banyak dibanding
Tabel 2 Hasil Penilaian dengan Skor Dimeglio

\begin{tabular}{ccc}
\hline Metode & Rata-rata Awal & Rata-rata Akhir \\
\hline Kite-Lovell & 12,3 & 4,1 \\
Ponseti & 11,9 & 3,2 \\
\hline
\end{tabular}

perempuan, yaitu 36 anak (56\%) berbanding 28 $\operatorname{anak}(44 \%)$.

Distribusi pasien berdasarkan kelompok usia saat mendapatkan penanganan inisial. Persentase terbanyak ialah pada kelompok pasien berusia 0-3 bulan dan 3-6 bulan. Hal ini merupakan kecenderungan yang baik dan menguntungkan dalam penanganan pasien CTEV karena sesuai dengan literatur bahwa penanganan pasien CTEV sebaiknya dimulai sedini mungkin. ${ }^{1}$

Usia pasien saat penanganan inisial terdiri dari 0-3 bulan (34 anak), 3-6 bulan (12 anak), 6 bulan-1 tahun (5 anak), sedangkan 1-2 tahun, 2-4 tahun, $>4$ tahun masing-masing berturut-turut 5,6 dan 2 anak.

Penanganan CTEV secara konservatif di RSHS, sebanyak 65 kaki (69\%) dilakukan dengan metode Kite-Lovell dan 39 (31\%) sisanya dengan metode Ponseti. Perbedaan jumlah ini disebabkan karena metode Ponseti di sini baru dilakukan pada tahun 2004, sehingga dari segi waktu, periode diaplikasikannya metode Kite-Lovell pun lebih lama dibandingkan dengan metode Ponseti dan tentunya jumlah pasien yang ditangani dengan metode Kite-Lovell juga lebih banyak.

Hasil penelitian menunjukkan perbandingan keadaan awal dan hasil akhir pasien yang ditangani dengan kedua metode, dinyatakan dengan angka skor derajat keparahan menurut Dimeglio. Tabel 2 menunjukkan bahwa rata-rata skor awal pada pasien yang ditangani dengan metode Kite-Lovell sebesar 12,3 sedangkan dengan metode Ponseti 11,9. Tidak ada perbedaan yang bermakna antara keduanya dan dinyatakan homogen menurut analisis statistik F-test. Dari 
Tabel 3 Tingkat Keberhasilan Menurut Kelompok Usia dan Metode Berdasarkan Jumlah Kaki yang Ditangani

\begin{tabular}{ccccc}
\hline \multirow{2}{*}{ Kelompok Usia } & \multicolumn{2}{c}{ Metode Kite - Lovell } & \multicolumn{2}{c}{ Metode Ponseti } \\
\cline { 2 - 5 } & Operasi & Tidak & Operasi & Tidak \\
\hline $0-3$ bulan & 1 & 39 & 1 & 19 \\
$3-6$ bulan & 2 & 8 & 0 & 8 \\
6 bulan -1 tahun & 3 & 2 & 1 & 1 \\
$1-2$ tahun & 3 & 0 & 3 & 0 \\
$2-4$ tahun & 4 & 0 & 3 & 0 \\
$>4$ tahun & 2 & 50 & 9 & 30 \\
Jumlah & 15 & & &
\end{tabular}

Tabel 4 Jumlah Pasien Menurut Klasifikasi CTEV

\begin{tabular}{lcccc}
\hline \multicolumn{1}{c}{ Kelompok Usia } & Idiopatik & Postural & Neurogenik & Sindromik \\
\hline $0-3$ bulan & 32 & & & 2 \\
$3-6$ bulan & 9 & 1 & & 1 \\
6 bulan -1 tahun & 2 & & & 2 \\
$1-2$ tahun & 3 & & & \\
$2-4$ tahun & 6 & & & \\
$>4$ tahun & 2 & $1(1,6 \%)$ & $1(1,6 \%)$ & $8(12,5 \%)$ \\
\hline Jumlah & $54(84 \%)$ &
\end{tabular}

hasil akhir setelah penanganan pun tidak ada perbedaan yang bermakna antara keduanya, ratarata skor Dimeglio pada Kite-Lovell adalah 4,1 dan Ponseti 3,2. Hasil ini berbeda dari penelitian sebelumnya yang sejenis di luar negeri, yang menyebutkan bahwa ada perbedaan bermakna pada hasil akhir antara penanganan CTEV secara konservatif, metode Ponseti memberikan hasil akhir yang lebih baik dibandingkan metode KiteLovell. ${ }^{5,6}$ Perbedaan hasil seperti ini terjadi karena adanya perbedaan dalam kualitas penanganan di masing-masing pusat penelitian. Subjektivitas juga kemungkinan mempengaruhi karena salah satu penelitian di luar negeri tersebut berasal dari Lembaga Ponseti.

Tabel 3 memperlihatkan bahwa penelitian ini digunakan klasifikasi usia dengan rentang yang lebih sempit pada usia dini yaitu dengan membedakan pasien berusia 0-3 bulan dengan 36 bulan, sementara penelitian sebelumnya umumnya hanya menggolongkan pasien kedalam kelompok 0-6 bulan. Tabel 4 menjelas-kan bahwa tingkat keberhasilan penanganan CTEV dengan cara konservatif akan lebih baik bila dilakukan lebih dini.

Tabel 4 menunjukkan pembagian subjek berdasarkan klasifikasinya. Kelompok yang pertama CTEV idiopatik, ditemukan pada anak yang tidak mempunyai kelainan penyerta lain, tidak akan membaik tanpa adanya penanganan intensif. Kedua, CTEV postural, akan sembuh cukup ditangani dengan manipulasi atau satu-dua casting. Ketiga, CTEV neurogenik yaitu CTEV yang tampak pada anak yang menderita mielomeningokel, dan pada kelompok keempat yaitu CTEV sindromik, terjadi pada anak yang juga menderita anomali lain seperti artrogrifosis, constriction bands, hemimelia tibia, dan lainlain. kelompok ketiga dan keempat, cenderung akan lebih rigid dan sukar untuk membaik walaupun telah diberi penanganan. Dari Tabel 4 terlihat bahwa 54 anak (84\%) ter-golong ke dalam CTEV idiopatik, 8 anak (12,5\%) CTEV sindromik, serta masing-masing 1 orang anak tergolong CTEV postural dan neurogenik.

CTEV akan lebih baik hasilnya bila ditangani lebih dini, namun demikian, untuk anak yang tergolong kedalam tipe CTEV sindromik dan neurogenik tampaknya tetap saja tidak akan memberikan hasil yang memuaskan.

Dari hasil penelitian ini, dapat disimpulkan bahwa tidak ada perbedaan bermakna hasil akhir penanganan secara konservatif antara metode Kite-Lovell dan Ponseti, angka keberhasilan berbanding lurus dengan usia yang lebih dini saat penanganan inisial.

\section{Pembahasan}

Hasil ini berbeda dengan penelitian-penelitian sebelumnya di luar negeri yang menyebutkan 
bahwa ada perbedaan bermakna pada hasil akhir antara penanganan CTEV secara konservatif, metode Ponseti memberikan hasil yang lebih baik dibandingkan metode Kite-Lovell. ${ }^{5,6}$ Perbedaan hasil seperti ini dapat terjadi adanya perbedaan dalam kualitas penanganan di masingmasing pusat penelitian. Subjektivitas juga kemungkinan mempengaruhi karena salah satu penelitian di luar negeri tersebut berasal dari Lembaga Ponseti.

CTEV akan lebih baik hasilnya bila ditangani lebih dini, namun untuk anak yang tergolong kedalam tipe CTEV sindromik dan neurogenik tetap tidak akan memberikan hasil yang memuaskan.

Dari penelitian ini, dapat disimpulkan bahwa tidak ada perbedaan bermakna dari hasil akhir penanganan secara konservatif antara metode Kite-Lovell dan Ponseti, angka keberhasilan berbanding lurus dengan usia yang lebih dini saat penanganan inisial.

\section{Daftar Pustaka}

1. Mosca V. The foot. Dalam: Morrisey RT, Weinstein S.L., penyunting. Lovell and Winter's pediatric orthopaedics Edisi ke-5. Philadelphia: Lippincott Williams \&
Wilkins; 2001, hlm.1151-216

2. Tachdjian MO. Pediatric orthopaedics. Edisi ke-3. Philadelphia : Saunders; 2001.

3. Cummings RJ, Davidson RS, Armstrong P, Lehman W. Congenital clubfoot. J Bone Joint Surg Am. 2002: 84:290.

4. Staheli LT. Pediatric orthopaedics secrets. Edisi ke-2. Philadelphia: Hanley \& Belfus; 2003.

5. Segev E, Keret D, Lokiec F, Yavor A, Wientroub S, Ezra $\mathrm{E}$, et al. Early experience with the Ponseti method for the treatment of congenital idiopathic clubfoot. IMAJ. 2005;7:79-86

6. Pirani S, Dietz F, Morcuende J, Mosca V, Herzenberg J, Weinstein S, et al. Clubfoot: Ponseti management. New York: Global-HELP Organization; 2003.

7. Richards B, Faulks S, Rathjen K, Karol L, Johmston C, Jones S. A comparison of two nonoperative methods of idiopathic clubfoot correction: the Ponseti method and the French functional (physiotherapy) method. J Bone Joint Surg Am. 2008 Nov; 90:2313-21.

8. Gerlach D, Gurnett C, Limpaphayom N, Alaee F, Zhang Z, Porter K, et al. Earlt result of the Ponseti method for the treatment of clubfoot associated with myelomeningocele. J Bone Joint Surg Am. 2009;91: 1350-59.

9. Solomon L, Warwick D, Nayagam S. Apley's system of orthopaedics and fractures. New Delhi: Ajanta Press; 2001.

10. Lehman BL, Atar D. Foot disorders in infancy. Dalam: Spivak J, Rokito D, penyunting. Orthopaedics a study guide. New York: McGraw and Hill; 2001. hlm 819-25. 